\title{
MODAL SOSIAL DALAM KEBERLANJUTAN PERTANIAN DI TENGAH ALIH FUNGSI LAHAN DI KELURAHAN BINTORO KECAMATAN PATRANG KABUPATEN JEMBER
}

\author{
Trio Pendi Setiawan ${ }^{1}$, Elok Ebrilyani ${ }^{2}$, Erina Nur Azilla ${ }^{3}$
}

Program Studi Agribisnis Fakultas Pertanian Universitas Jember

\begin{abstract}
Abstrak
Alih fungsi lahan merupakan permasalahan sektor pertanian, salah satunya terjadi di Kelurahan Bintoro Kecamatan Patrang Kabupaten Jember. Alih fungsi lahan menyebabkan keresahaan masyarakat petani di Bintoro. Modal sosial merupakan hal yang dapat mendukung keberlanjutan pertanian di tengah alih fungsi lahan. Tujuan penelitian ini adalah untuk mengetahui bagaimana modal sosial dapat mendukung keberlanjutan pertanian di tengah alih fungsi lahan di Kelurahan Bintoro. Metode penelitian ini menggunakan metode deskriptif kualitatif dengan pendekatan studi kasus dengan teknik penentuan informan menggunakan purposive dengan beberapa kriteria. Hasil dari penelitian bahwa Modal sosial dalam keberlanjutan pertanian di tengah alih fungsi lahan di Kelurahan Bintoro terdiri dari beberapa kategori yang dilakukan menurut Abdullah (2003) modal sosial terdiri dari kepercayaan, norma, dan jaringan. Kepercayaan sangat dibutuhkan untuk memberikan dorongan untuk saling memperkuat. Norma memberikan aturan di dalam kehidupan masyarakat. Jaringan menandakan kekuatan di dalam membangun sutau relasi. Hasil penelitian ini menunjukkan bahwa bentuk konkrit modal sosial seperti terjalinnya hubungan harmonis di dalam kehidupan pertanian, tercipta rasa saling tolong menolong, berjalannya kegiatan pertanian, kemudahan di dalam memperoleh input atau fasilitas pertanian, dan beberapa bentuk lainnya. Berdasar kondisi tersebut kegiatan pertanian masih terus dapat berjalan karena dasar kehidupan masyarakat petani yang masih kokoh di dalam mempertahankan usaha pertanian mereka.
\end{abstract}

Kata Kunci: alih fungsi lahan, modal sosial, pertanian

\section{Abstract}

Land use change is a problem of the agricultural sector, one of which occurred in Bintoro Village, Patrang District, Jember Regency. Land conversion has led to the concern of the farming community in Bintoro. Social capital is something that can support the sustainability of agriculture in the midst of land conversion. The purpose of this research is to study how social capital can support the sustainability of agriculture in the midst of land conversion in the Bintoro Village.This research method uses descriptive qualitative method with a case study approach with the technique of determining informants using purposive sampling. The results of the study that social capital in the sustainability of agriculture in the middle of land use change in Kelurahan Bintoro consists of several categories, namely trusts, norms, and networks. Trust is needed to provide encouragement to strengthen each other. Norms provide rules in people's lives. Networks signify strength in building relationships. Concrete forms of social capital support such as establishing harmonious relationships in agricultural life, creating mutual assistance to help, the running of agricultural activities, ease in obtaining agricultural inputs or facilities, and several other forms. Based on these conditions agricultural activities can continue to run because the basic community life of farmers who are still strong in maintaining their agricultural business.

Keywords: Agricilture, Conversion of land, Social Capital. 


\section{Pendahuluan}

Pertanian merupakan kegiatan memproduksi sesuatu dari makhluk hidup baik tanaman maupun hewan untuk memenuhi kebutuhan manusia disertai kegiatan memperbaharui, memproduksi, dan mempertimbangkan fator ekonomis, namun pertanian banyak diartikan dalam arti sempit yaitu hanya sebatas pada bercocok tanam dan bertujuan untuk menghasilkan produk pertanian. Pertanian memiliki beragam bidang yaitu pertanian, perkebunan, kehutanan, perikanan, dan peternakan. Kegiatan pertanian yang cukup luas dan mencakup berbagai bidang menjadikan perlunya pemenuhan sumberdaya yang mendukung dan juga tidak terlepas dari berbagai kendala yang perlu dihadapi (Suratiyah, 2015).

Pertanian dapat dikatakan sebagai kegiatan yang penuh risiko dengan ditandi adanya berbagai kendala (Sunarso, 2017). Kendala-kendala yang dimaksud yaitu berupa kendala biofisik, ekonomi, maupun sosial. Kendala sosial merupakan salah satu kendala yang pasti dialami, mengingat kehidupan sosial masyarakat selalu dinamis. Kendala sosial yang terjadi seperti keterbatasan dalam membangun hubungan sosial yang menyeluruh, apalagi jika terdapat perbedaan kebudayaan, norma atau kebiasaan. Kendala ini tentu akan memberikan pengaruh terhadap ikatan sosial pada kehidupan masyarakat. Ikata sosial masyarakat sangat penting karena perannya dalam pembangunan hubungan masyarakat menjadi tetap harmonis. Keharmonisan tersebut menjadi hasil dari modal sosial yang dimiliki oleh masayarakat khususnya petani sebagai pelaku kegiatan pertanian sekaligus penyokon dalam pembangunan pedesaan (Fukuyama, 1999).

Modal sosial merupakan salah satu aspek penting dalam pembangunan manusia dan sosial, ekonomi maupun politik. Menurut Abdullah (2013), unsur-unsur modal sosial yang ada di masyarakat diantaranya adalah rasa percaya (trust), nilai/norma (norms) dan jaringan (network). Ketiga elemen modal sosial menjadi kekuatan dalam masyarakat sebagai perekat komunitas, jembatan serta koneksi/akses. Elemen dalam modal sosial yang memberikan manfaat yang bisa diakses oleh komunitas yang terikat. Unsur-unsur tersbebut juga tentu tidak bertentangan secara universal karena memiliki standar berlaku tersendiri sesuai dengan kultur suatu daerah. Modal sosial menjadi salah satu bentuk dukungan di tengah kendala yang megikis ikatan sosial dalam kelompok masyarakat. Permasalahan yang kali ini menjadi pusat perhatian yaitu terjadinya konversi atau alih fungsi lahan yang sedang marak terjadi. kondisi tersebut tentu dapat merenggut lahan pertanian yang menjadi sumber penghasilan utama khususnya bagi keluarga petani (Anggita, 2013).

Kelurahan Bintoro Kabupaten Jember merupakan salah satu daerah yang telah mengalami perubahan di dalam penggunaan lahan. Sebagian besar lahan di kelurahan Bintoro merupakan lahan pertanian, kurang lebih $79 \%$ dari total lahan Kelurahan Bintoro atau 8.403,23 ha merupakan lahan pertanian, namun sejalan dengan waktu banyak lahan yang beralihfungsi menjadi lahan pemukiman. lahan pertanian yang megalami alih fungsi lahan sebesar $50 \%$ dari lahan pertanian sebelumnya atau 4.403,6 ha. Kondisi ini tentu menimbulkan permasalahan di dalam sektor pertanian. Lahan yang menjadi kunci di dalam kegiatan pertanian telah mengalami penyempitan akibat pengalihfungsian lahan. Pengalihfungsian lahan ini menjadikan banyak para petani yang mengami keresahan berupa munculnya beberapa kesulitan di dalam menjalani kehidupannya. Kondisi ini menjadikan para petani banyak memutar otak untuk dapat terus menghidupi dirinya maupun keluarganya. Cara yang digunakan yaitu dengan memanfaatkan modal sosial yang terdapat di lingkungan Kelurahan Bintoro. Modal sosial dapat dimanfaatkan para petani Bintoro untuk tetap 
melanjutkan pertaniannya meskipun alih fungsi lahan tetap terjadi. Para petani dapat bertahan dengan adanya rasa kepercayaan yang tinggi, ikatan jaringan yang kuat serta norma yang masih tetap terjaga baik. Alasan ini yang menjadi perhatian peneliti ingin mengulas dan menganalisis kunci keberlanjutan pertanian ditengah alih fungsi lahan melalui konsep modal sosial. Tujuannya adalah mengetahui bagaimana modal sosial terapkan masyarakat di kelurahan Bintoro untuk mendukung keberlanjutan pertanian di Kelurahan Bintoro. Berdasarkan fenomena tersebut tercetus tulisan dengan judul penelitian "Modal Sosial dalam Keberlanjutan Pertanian di Tengah Alih Fungsi Lahan di Kelurahan Bintoro Kabupaten Jember".

\section{Metode Penelitian}

Penelitian dilakukan di daerah Kelurahan Bintoro Kabupaten Jember dengan menggunakan purposive method dan adanya berbagai pertimbangan. Pertimbangan yang diambil yaitu Kelurahan Bintoro memiliki persoalan yang cukup menarik untuk diangkat berupa terjadinya alih fungsi lahan menjadi lahan perumahan atau pemukinan yang terus terjadi yaitu mulanya lahan pertanian $80 \%$ sekarang menjadi 50\% menjadi lahan pemukiman. Penelitian pada lokasi ini juga akan mendukung keberlanjutan pertanian yang semakin kokoh dengan memanfaatkan modal sosial yang telah ada (Berlian, 2014).

Metode penelitian ini menggunakan metode deskriptif kualitatif dengan pendekatan studi kasus. Berdasarkan penjelasan tersebut, bahwa pada metode deskriptif kualitatif merupakan metode dengan mengembangkan fenomena yang terjadi agar dapat diperoleh keterkaitan dan penyelesaian yang dapat dilakukan (Raco, 2010). Pendekatan dilakukan dengan pendekatan studi kasus. Pendekatan tersebut sangat sesuai dengan penerapan pada penelitian ini yang mengangkat modal sosial dari ikatan sosial di kehidupan masyarakat. (Daymon dan Holloway, 2008).

Teknik penentuan informan dalam penelitian ini yaitu dilakukan secara purposive dengan beberapa kriteria yang ada di lapang. Menurut Johnson dan Christensen (2017), metode purposive merupakan metode yang diterapkan secara sengaja untuk memilih informan sebagai sumber data di dalam penelitian ini. Beberapa pertimbangan atau kriteria yang diterapkan dalam penentuan informan yang nyata dan operasional yaitu memilih kelompok tani dan petani yang sudah memiliki pengalaman bertani lebih dari 20 tahun. Informan yang digunakan dalam penelitian yaitu informan berjumlah 10 orang yang bekerja sebagai petani di Kelurahan Bintoro. Informan dalam penelitian diantaranya petani sebanyak 9 orang yang dahulu memiliki banyak lahan sawah kini hanya tinggal beberapa petak saja akibat alih fungsi lahan dan 1 orang sebagai ketua kelompok tani di Kelurahan Bintoro yaitu Bapak Suradi.

Penelitian ini memerlukan informan kunci yaitu berasal dari ketua kelompok tani dan petani yang mengalami penyempitan lahan akibat alih fungsi lahan. Kedua informan tersebut diambil sebagai informan kunci karena informasi yang diperlukan di dalam penelitian ini yaitu mencakup kondisi mdal sosial di dalam mendukung keberlanjutan pertanian. Peran petani di dalam penelitian ini juga berperan sebagai obyek utama penelitian, sehingga informasi yang diperoleh dari petani secara langsung menjadi dasaran di dalam penelitian ini. Besar informasi yang diperoleh dapat terlihat dari kedalaman data yang diperoleh dan disertai oleh dukungan informasi dari beberapa institusi terkait yang menjadi informan pendukung

Kriteria lain yaitu:

1. Seseorang yang telah berkecimpung secara mendalam terhadap fokus penelitian. 
2. Adanya ketersediaan waktu yang dimiliki pada saat bertemu maupun memberikan informasi penelitian.

3. Mampu dan dapat memberikan informasi yang dibutuhkan penelitian.

4. Seseorang yang dapat memberikan informasi sesuai kondisi yang sedang terjadi atau informan tidak bertidak bohong atau tidak berusaha untuk menutup-nutupi informasi kepada peneliti.

Metode pengumpulan data merupakan suatu teknik dalam pengumpulan data yang menjadi informasi yang dibutuhkan di dalam suatu penelitian. Metode pengumpulan data yang digunakan dalam penelitian ini yaitu wawancara dan observasi dengan alat bantu berupa catatan lapang dan data dokumentasi dari lembaga, instansi, maupun sumber lain yang terkait. Masing-masing metode tersebut digunakan untuk saling melengkapi antara satu dengan yang lain, sehingga diperoleh data lengkap (jenuh). Wawancara dilakukan secara mendalam (in depth interview) terhadap informan-informan pada penelitian ini. Jenis wawancara yang dilakukan yaitu wawancara bebas terpimpin dengan adanya perpaduan antara daftar pertanyaan yang telah disediakan dan pertanyaan yang diajukan secara spontan. observasi menjadi kegiatan yang mengawali proses pencarian fenomena atau kondisi yang sebenarnya sedang terjadi. Pengamatan yang dilakukan mencakup kondisi dan situasi yang sedang terjadi dari segi aktivitas petani, hubungan sosial, maupun kondisi ekonomi petani. Data hasil observasi nantinya akan dijadikan sebagai data yang mendasari ataupun data yang mendukung penelitian ini. Selanjutnya Dokumentasi untuk memberikan informasi menyangkut sejarah, data perkembangan pertanian, peningkatan inovasi adopsi, maupun informasi yang berkaitan dalam penelitian ini.

Metode analisis data pada penelitian ini yaitu menggunakan model Miles dan
Huberman. Menurut Miles et al (2014), model analisis ini telah sering digunakan di dalam penelitian kualitatif. Alasan yang mendasari ketersesuaiannya. yaitu mencakup awal dimulainya penelitian di dalam perolehan data sampai pada proses lanjutan berupa penarikan kesimpulan. Model analisis ini dilakukan mulai dari pengumpulan data secara langsung dari lapang, reduksi data, penyajian data, dan penarikan kesimpulan.

Uji keabsahan data dalam penelitian ini yaitu menggunakan uji credibility (validitas internal), transferability (validitas eksternal), dependability (reabilitas), dan confirmability (obyektifitas). Pengujian kredibilitas pada penelitian yaitu dengan cara triangulasi data. Triangulasi merupakan cara dalam pengujian data dengan menguji ketepatan dari hasil penelitian lanjutan dengan penelitian ulang. Terdapat pertimbangan di dalam penggunaan triangulasi tersebut, yaitu peneliti memiliki keterbatasan waktu dalam penelitian, sehingga triangulasi yang paling efektif, efisien, dan realistis berupa triangulasi teknik pengumpulan data dan triangulasi sumber. Triangulasi sumber ini juga akan mengungkap kebenaran yang sebenarnya dibalik kenyataan yang dicoba untuk ditutup-tupi oleh salah satu atau seluruh sumber infomasi. Uji transferability yaitu dengan melihat pengiriman informasi yang sesuai antara penerima dan pengirim informasi, sehingga semua pihak dapat memahami hasil penelitian. Pengujian dependability penelitian modal sosial dalam keberlanjutan pertanian nantinya akan di audit oleh auditor independen untuk menguji ketersesuaian dan keaslian dari penelitian yang dilakukan. Uji Konfirmability merupakan pengujian yang menyangkut persetujuan oleh beberapa pihak sehingga hasil penelitian ini didukung dan disepakati bersama. 


\section{HASIL DAN PEMBAHASAN}

\section{Gambaran Umum Daerah Penelitian}

Kabupaten Jember merupakan salah satu kabupaten yang terletak di Provinsi Jawa Timur dengan luas yaitu $3.293,34 \mathrm{~km}^{2}$. Kabupaten Jember terbagi menjadi 31 Kecamatan. Dalam penelitian ini yang menjadi lokasi peneliti adalah Kelurahan Bintoro yang terletak di Kecamatan Patrang. Kelurahan Bintoro merupakan kelurahan terluas di Kecamatan Patrang dengan luas $8,44 \mathrm{~km}^{2}$ serta ketinggian 146 mdpl. Kelurahan Bintoro terdiri dari tiga dusun diantaranya Gluduk, Mojan, dan Perbal. Batas-batas Kelurahan Bintoro yaitu:

Bagian Utara : Kelurahan Kemuning Lor Bagian Barat : Kelurahan Jumerto Bagian Selatan: Kelurahan Slawu dan Kelurahan Patrang

Bagian Timur : Kelurahan Baratan

Tabel 1.

Jumlah Penduduk di Kelurahan Bintoro Tahun 2016-2018 Berdasarkan Jenis Kelamin

\begin{tabular}{|c|c|c|c|c|c|}
\hline $\begin{array}{l}\mathrm{N} \\
\mathrm{o}\end{array}$ & $\begin{array}{c}\text { Tah } \\
\text { un }\end{array}$ & $\begin{array}{c}\text { Pere } \\
\text { mpu } \\
\text { an }\end{array}$ & $\begin{array}{l}\text { Laki } \\
\text {-laki }\end{array}$ & $\begin{array}{c}\text { Juml } \\
\text { ah }\end{array}$ & $\begin{array}{l}\text { Kepadatan } \\
\text { Penduduk } \\
\left(\mathrm{Jiwa}^{2} / \mathrm{km}^{2}\right)\end{array}$ \\
\hline \multirow{2}{*}{1} & \multirow{2}{*}{2016} & 5.42 & 5.11 & 10.5 & 1.249 \\
\hline & & 6 & 6 & 42 & \\
\hline \multirow{2}{*}{2} & \multirow{2}{*}{2017} & 5.45 & 5.14 & 10.5 & 1.255 \\
\hline & & 1 & 0 & 91 & \\
\hline \multirow{2}{*}{3} & \multirow{2}{*}{2018} & 5.47 & 5.16 & 10.6 & $1.260,31$ \\
\hline & & 4 & 3 & 37 & \\
\hline
\end{tabular}

Sumber: BPS Kabupaten Jember, 2019

Berdasarkan tabel 1, menyatakan bahwa jumlah penduduk di Kelurahan Bintoro didominasi oleh perempuan dibandingkan lelaki, dengan total jumlah penduduk dan kepadatan penduduk mengalami peningkatan setiap tahunnya. Pada tahun 2018 jumlah penduduk 10.637 dengan rasio jenis kelamin 94,32.

Tabel 2.

Banyaknya Rumah Tangga Menurut Mata Pencaharian Pokok di Kelurahan Bintoro Tahun 2017

No Mata Pencaharian Jumlah

\begin{tabular}{llr}
\hline 1 & Pertanian & 2.191 \\
\hline 2 & Buruh tani & 943 \\
\hline 3 & PNS & 44 \\
\hline 4 & BUMN & - \\
\hline 5 & Tukang & 221 \\
\hline 6 & Karyawan Swasta & 1.306 \\
\hline 7 & Lain-Lain & 775 \\
\hline & Jumlah & 5.480 \\
\hline
\end{tabular}

Sumber: BPS Kabupaten Jember, 2018

Berdasarkan tabel 2, menunjukkan hasil bahwa mata pencaharian atau pekerjaan utama penduduk Kelurahan Bintoro berasal dari sektor pertanian. Umumnya penduduk Kelurahan Bintoro bekerja sebagai petani serta buruh tani pada berbagai kegiatan pertanian, misalnya dalam berbagai kegiatan matun, panen, memupuk, tanam, dan lain-lain.

Tabel 3. Klasifikasi Umur Informan

\begin{tabular}{ccrr}
\hline No & $\begin{array}{c}\text { Klasifikasi } \\
\text { Umur } \\
\text { Informan }\end{array}$ & $\begin{array}{c}\text { Jumlah } \\
\text { (orang) }\end{array}$ & $\begin{array}{c}\text { Persentase } \\
(\%)\end{array}$ \\
\hline 1 & $<20$ tahun & 1 & 10 \\
\hline 2 & $20-29$ tahun & 1 & 10 \\
\hline 3 & $30-39$ tahun & 2 & 20 \\
\hline 4 & $40-49$ tahun & 2 & 20 \\
\hline 5 & $>49$ tahun & 4 & 40 \\
\hline & Jumlah & 10 & 100 \\
\hline
\end{tabular}

Sumber: Data Primer, 2019.

Berdasarkan tabel 3, menunjukkan bahwa informan dalam penelitian mayoritas berada pada kelompok umur 40-49 tahun sebanyak 4 informan dengan rasio persentase sebesar $40 \%$, sedangkan yang terendah berada pada umur tidak lebih dari 20 tahun serta umur 20-29 tahun dengan masing-masing berjumlah 1 orang.

Tabel 4.

Klasifikasi Informan Berdasarkan Tingkat Pendidikan Terakhir

\begin{tabular}{llrr}
\hline No & $\begin{array}{c}\text { Tingkat } \\
\text { Pendidikan } \\
\text { Terakhir }\end{array}$ & $\begin{array}{r}\text { Jumlah } \\
\text { (orang) }\end{array}$ & $\begin{array}{c}\text { Persentase } \\
(\%)\end{array}$ \\
\hline 1 & SD & 5 & 50 \\
\hline 2 & SLTP & 3 & 30 \\
\hline 3 & SLTA & 2 & 20 \\
\hline 4 & Diploma/ & - & - \\
\hline
\end{tabular}




\begin{tabular}{ccc}
\hline Sarjana & & \\
\hline Jumlah & 10 & 100 \\
\hline
\end{tabular}

Sumber: Data Primer, 2019

Berdasarkan tabel di atas, menunjukkan bahwa tingkat pendidikan akhir informan dalam penelitian kali ini mayoritas adalah berpendidikan setara SD yaitu sebanyak 5 informan atau separuh dari jumlah total informan dengan persentase 50\%, sedangkan terendah yaitu setara SLTA/SMA sebanyak 2 informan dengan persentase $20 \%$. Hal tersebut karena mayoritas penduduk di Kelurahan Bintoro yang bekerja sebagai petani adalah lulusan Sekolah Dasar.

Tabel 5.

Klasifikasi Luas Lahan Milik Informan

\begin{tabular}{ccrr}
\hline No & $\begin{array}{c}\text { Luas } \\
\text { Lahan }\end{array}$ & $\begin{array}{c}\text { Jumlah } \\
\text { (orang) }\end{array}$ & $\begin{array}{c}\text { Persentase } \\
(\%)\end{array}$ \\
\hline 1 & $0-0,1 \mathrm{Ha}$ & 4 & 40 \\
\hline 2 & $0,1-0,2 \mathrm{Ha}$ & 4 & 40 \\
\hline 3 & $0,2-0,3 \mathrm{Ha}$ & 2 & 20 \\
\hline 4 & $>0,3 \mathrm{Ha}$ & - & - \\
\hline & Jumlah & 10 & 100 \\
\hline
\end{tabular}

Sumber: Data Primer, 2019

Berdasarkan tabel 5, menunjukkan bahwa luas lahan pertanian yang digarap oleh petani informan mayoritas berlahan sempit yaitu <0,2 $\mathrm{Ha}$ atau $2000 \mathrm{~m}$. Mayoritas petani informan membudidayakan tanaman tembakau, padi, dan ubi kayu. Seperti yang diketahui, bahwa di lokasi penelitian komoditas utama yang dihasilkan adalah tembakau. Lahan petani dahulu sangatlah luas bahkan ada beberapa informan yang memiliki luas lahan $>0,5 \mathrm{Ha}$, namun karena terdapat alih fungsi lahan yang menyebabkan berkurangnya lahan pertanian sehingga rata-rata petani saat ini memiliki luas lahan yang sempit.

\section{Modal Sosial dalam Keberlanjutan Pertanian di Tengah Alih Fungsi Lahan di Kelurahan Bintoro Kabupaten Jember}

Alih fungsi lahan merupakan suatu hal yang sering terjadi di sebagian daerah, tak terkecuali di Kelurahan Bintoro. Pengalihfungsian lahan terjadi dari lahan yang umumnya berupa lahan pertanian beralih menjadi lahan perumahan ataupun industri, dimana luas lahan alihfungsi semakin tahun semakin meluas yang akan berpengaruh terhadap keberlanjutan pertanian. Berbagai upaya telah dilakukan, salah satunya dengan menjaga sistem pertanian dapat terus berjalan. Upaya lain yang dilakukan dengan memanfaatkan modal sosial yang dimiliki oleh masingmasing individu (petani) ataupun yang dimiliki sekelompok petani (kelembagaan pertanian).

Modal sosial memiliki beberapa kategori, seperti kepercayaan (trust), norma (norm), dan jaringan (network) yang dapat mendorong pencapaian tujuan yaitu keberlanjutan pertanian di Kelurahan Bintoro untuk mencegah atau bahkan mengatasi berbagai bentuk permasalahan yang ada. Kegiatan pertanian yang ada di kehidupan masyarakat telah mencakup suatu bentuk kompleksitas. Berdasarkan kondisi ini perlu adanya modal sosial di dalam menciptakan kondisi yang sesuai. Modal sosial yang berkembang di kehidupan masyarakat, khususnya para petani di Kelurahan Bintoro dapat terlihat dari informasi mengenai kepercayaan antar masyarakat, norma di kehidupan masyarakat, dan jaringan yang tercipta di dalam hubungan sosial masyarakat. Masing-masing kategori akan menjelaskan bentuk dukungan yang dilakukan di dalam keberlanjutan pertanian. Dukungan yang didapatkan dari informasi masyarakat, khususnya pada petani dan ketua kelompok tani.

\section{Kepercayaan}

Kepercayaan yang terjalin antar petani informan di Kelurahan Bintoro memiliki beragam bentuk manfaat. Kemanfaatan dari rasa kepercayaan tersebut dapat memberikan bentuk kerjasama di dalam menjalankan kegiatan pertanian. Rasa kepercayaan juga memberikan hubungan yang harmonis di dalam masyarakat. Komitmen atas rasa kepercayaan dapat terjadi sepanjang masing-masing pihak dapat terus percaya dan tidak menyalahi rasa kepercayaan yang diberikan. Kondisi 
ini yang mendorong hubungan antar petani semakin berkualitas. Manfaat dari kepercayaan ini didukung oleh adanya pernyataan Bapak Suradi selaku ketua kelompok tani sebagai berikut:

"Ya itu untuk ee ini ee peminjaman alatalat, karena sudah percaya ya sudah, sudah saya percayakan masalah peminjaman alat-alat pertanian, tidak ada kecurigaan buat lain-lain" (Wawancara, 28 Oktober 2019).

Pernyataan tersebut juga didukung oleh Bapak Romlah sebagai petani sebagai berikut:

"Yehh alhamdulillah, yeh bedeh bein lantaran dari rezekih aroah, dari anakanak, dari tan teretan, sosial bedeh beih" (Wawancara, 30 Oktober 2019).

Kedua pernyataan tersebut menunjukkan adanya manfaat penting dari adanya rasa kepercayaan dalam kegiatan pertanian yaitu berupa memberikan pinjaman peralatan pertanian yang dilakukan antar petani. Manfaat kepercayaan lainnya yaitu dasar rasa percaya menjadi sumber bantuan ataupun sumber pendapatan yang diperoleh dari berbagai pihak. Masing-masing individu di dalam masyarakat akan saling membantu saudara ataupun anggota masyarakat lain di dalam menghadapi kesulitan atau persoalan. Hal tersebut didukung hasil penelitian oleh Rahmadi dan Santoso (2016) yang menyatakan manfaat kepercayaan dapat memperkuat hubungan yang terjadi antar petani karena adanya interaksi secara terus menerus dan berulang kali, dimana kepercayaan tersebut dapat membantu memecahkan permasalahan yang dihadapi oleh petani. Kepercayaan tidak akan tidak terjadi jika dua orang atau lebih yang terlibat dalam membentuk suatu hubungan yang saling bantu-membantu tersebut tidak saling percaya.

Rasa kepercayaan dalam hubungan sosial antar petani dapat mengalami suatu perkembangan. Perkembangan kepercayaan yang dimaksud yaitu ketika hubungan sosial atas rasa kepercayaan semakin erat. Perkembangan dapat terlihat dari proses kepercayaan antar petani dari yang masih mencoba memberikan rasa kepercayaan kepada orang lain. Rasa kepercayaan tersebut semakin erat tergantung dengan kondisi ataupun sikap yang dimiliki masing-masing pihak, salah satunya berupa bentuk sikap jujur dari para petani. Berdasarkan kondisi yang ada di Kelurahan Bintoro telah terjalin perkembangan kepercayaan, apalagi rasa kepercayaan tersebut juga didapatkan karena hubungan darah ataupun sifat masyarakat yang masih saling mempercayai antar petani. Berikut pernyataan dari Bapak Suradi sebagai ketua kelompok tani yang mendukung perkembangan kepercayaan.

"Yaa harus ee.. terutama untuk pengurusnya.. itu pengurus juga seharusnya juga itupun jujurlah.. ee dalam organisasi. Masalahnya kalau tidak jujur yang pasti tidak akan dipercaya sama anggotanya" (Wawancara, 28 Oktober 2019).

Pernyataan tersebut juga didukung oleh petani lain yaitu Bapak Untung sebagai berikut.

"Bennyak Cong, bennyak.. yang pertama ya rumah tangga, walaupun se seng jeuh ye percajeh" (Wawancara, 30 Oktober 2019).

Kedua pernyataan di atas menunjukkan bahwa perkembangan kepercayaan dimulai dari lingkup terkecil yaitu keluarga yang akan meluas hingga masyarakat luas. Kepercayaan yang ada akan semakin besar sejalan banyaknya pihak yang memberikan rasa kepercayaan. Salah satu faktor-faktor yang bisa memberikan dampak terhadap perkembangan pertanian yaitu rasa kejujuran. Kejujuran sebagai kunci rasa kepercayaan, sebagaimana berkembang di dalam suatu kelompok tani di Kelurahan Bintoro. Ketidakjujuran oleh pengurus kelompok tani akan merusak kepercayaan 
antar petani yang telah terbangun dengan baik.

\section{Norma}

Kategori modal sosial selanjutnya yaitu norma di dalam kehidupan masyarakat termasuk pertanian. Norma menjadi bentuk aturan yang harus ditaati. Norma tersebut berkembang dari generasi ke generasi dengan mengembangkan rasa saling menghormati antar sesama petani. Perkembangan norma di kehidupan pertanian Kelurahan Bintoro menciptakan kerukunan dan kedamaian. Norma berkembang secara horizontal yang menandakan bahwa norma berlaku bagi seluruh petani tanpa ada yang dispesialisasikan. Norma yang berkembang di dalam petani sesuai pernyataan Bapak Suradi sebagai ketua kelompok tani yaitu sebagai berikut:

"Yang jelas itu ada, ada.. dari normanorma kehidupan itu ada, seperti halnya ee petani yang masih muda itu ya ndak mungkin merendahkan yang tua (sambil tertawa).. ya harus menghormati. Ya harus menghormatilah ke yang lebih tua." (Wawancara, 28 Oktober 2019).

Pernyataan tersebut juga didukung oleh Bapak Basuki sebagai petani yaitu sebagai berikut:

"Yaa.. bagus-bagus lah.. ya secara umum rukun, damai, riyah" (Wawancara, 30 Oktober 2019).

Pernyataan perkembangan norma tersebut menunjukkan norma kehidupan berkembang di berbagai lingkup termasuk pertanian. Salah satu bentuk norma yang ada yaitu berbentuk perilaku masyarakat yang saling menghormati, terutama pada seseorang yang lebih tua. Norma yang ada di dalam masyarakat berjalan secara rukun dan damai. Kehidupan tersebut dapat terjadi karena ada norma yang berkembang dan mengatur kehidupan masyarakat di Kelurahan Bintoro. Sejauh ini perkembangan norma dapat dikatakan baik di tengah perkembangan zaman saat ini. Norma yang berperan sebagai aturan memberikan hasil yang berbentuk perilaku masyarakat khususnya petani di Kelurahan Bintoro. Dampak dari pelaksanaan norma cenderung untuk kebaikan para petani itu sendiri. Ketiadaan norma akan berdampak buruk terhadap kehidupan pertanian yaitu keharmonisan antar petani akan terganggu dan tidak terbentuk rasa kekeluargaan di antara mereka yang berakibat terjadinya permusuhan. Contoh konkrit seperti peminjaman alat modal, kerjasama, dan berbagai bentuk lain yang terganggu. Berikut pernyataan Bapak Suradi sebagai ketua kelompok tani menyangkut dampak norma sebagai modal sosial di dalam keberlanjutan pertanian.

"Mungkin ya bisa, pada artinya dalam manfaatnya ee.. tujuan pertanian itu bisa saling bantu membantu, yang jelas satu sama yang lain saling bantu ya karena butuh bantuan satu sama yang lain, trus kalau rukun insya Allah bakal lancar" (Wawancara, 28 Oktober 2019).

Pernyataan tersebut juga didukung oleh Bapak Imam selaku informan petani sebagai berikut:

"De iyyeh, tak olleh sumbangan. Mon norok ye olleh sumbangan" (Wawancara, 30 Oktober 2019).

Berdasarkan pernyataan tersebut menunjukkan bahwa norma yang ada di dalam kehidupan petani di Kelurahan Bintoro memberikan dampak yang positif berupa perilaku saling membantu antar petani. Sikap saling membantu yang telah berakar pada hati masyarakat menjadi dukungan yang sangat penting di tengah berbagai bentuk permasalahan yang terjadi di dalam kehidupan. Permasalahan utama yang terjadi berdasarkan pada fenomena yang di lapang menunjukkan terjadinya kegoyahan pada keberlanjutan pertanian di tengah kegiatan alih fungsi lahan pertanian yang kini telah mulai menilik Kelurahan Bintoro di dalam pembangunan perumahan. Sikap saling membantu ini juga berbentuk semacam pemberian sumbangan sebagai bentuk dukungan, 
utamanya secara materil. Petani yang membutuhkan bantuan akan banyak dibantu oleh orang lain, apabila petani tersebut rajin dan mau membantu sesamanya di dalam menjaga keberlangsungan pertaniannya.

\section{Jaringan}

Jaringan menjadi salah satu bentuk kekuatan yang terdapat pada diri masingmasing petani yang berupa luasnya relasi yang dimiliki untuk saling mengenal dan berinteraksi. Kekuatan jaringan akan memberikan berbagai bentuk manfaat pada perkembangan pertanian yang dijalankan oleh para petani informan di Kelurahan Bintoro. Manfaat jaringan dapat berupa hal sederhana yang hanya untuk berkomunikasi atau kumpul bersama-sama, bahkan pembentukan kerjasama di bidang pertanian serta penyaluran informasi dari informan ke penerima informasi. Berikut pernyataan dari Bapak Suradi terkait perolehan informasi sebagai berikut:

“...Untuk me me menimba-nimba ilmuilmu yang masih belum ia miliki (tertawa sedikit). Seperti menanam .. ee.. labu itu kan itu belum terlalu mengerti tentang labu itu kok diambil bijinya" (Wawancara, 28 Oktober 2019).

Pernyataan tersebut juga didukung oleh petani Bapak Mahfud selaku petani sebagai berikut:

"Ya.. Alhamdulillah cong.. deddih tiap-tiap musim atau hari raya atau ada musibah itu.. enaklah.. itu enak" (Wawancara, 30 Oktober 2019).

Pernyataan di atas menunjukkan bahwa manfaat jaringan seperti adanya perolehan informasi, ilmu, dan bantuan di dalam melaksanakan kegiatan pertanian. Kegiatan pertanian yang melekat erat dengan risiko ketidakpastian yang salah satunya dapat berbentuk musibah yang mungkin terjadi di Kelurahan Bintoro yaitu seperti adanya serangan hama dan penyakit yang berakibat pada penurunan produksi sekaligus pendapatan petani. Jaringan juga dapat memberikan dukungan berupa peningkatan kemampuan (skill) petani di dalam melakukan pembudidayaan tanaman seperti menciptakan diversifikasi pembudidayaan tanaman yang diterapkan untuk mengoptimalkan pendapatan serta menciptakan budaya penanaman baru di Kelurahan Bintoro.

Perkembangan jaringan berjalan cukup cepat sesuai dengan kemampuan masingmasing petani di dalam membangun relasi untuk memperkuat hubungan sosial yang ada, sehingga dapat dimanfaatkan secara optimal terutama pada kegiatan pertanian yang saat ini tengah mengalami sebuah ancaman alih fungsi lahan. Perkembangan jaringan juga tidak serta merta berjalan lancar. Terdapat beberapa hal yang dapat terjadi, baik itu memperkuat jaringan atau melemahkan jaringan yang ada. Berikut terdapat pernyataan dari Bapak Suradi selaku ketua kelompok tani yang menunjukkan perkembangan jaringan di sektor pertanian di Kelurahan Bintoro.

"Kalau masalah kendala itu ee.... Ndak ada ndak ada, kalau manfaatnya banyak. Masalahnya kalau ee kalau tidak jadi atau tidak berhasil itu biasanya ditanamkan lagi nantik sampek hasil itu, kan bermanfaat. Tidak ada masalah" (Wawancara, 28 Oktober 2019).

Pernyataan tersebut juga didukung oleh Bapak Joko selaku petani sebagai berikut:

"He.. contohnya jeriyeh.. (berhenti sejenak).. contohnya roah, yeh kesalahpahaman" (Wawancara, 30 Oktober 2019).

Berdasarkan pernyataan di atas menunjukkan tidak ada kendala yang cukup besar pada perkembangan jaringan di sektor pertanian. Perkembangan jaringan antar informan di Kelurahan Bintoro masih dapat dikatakan baik serta kendalanya sangat minim. Kendala yang mungkin terjadi hanya berupa adanya kesalahpahaman, meski kesalahpahaman juga tidak sering terjadi. Upaya yang dapat dilakukan dengan adanya kendala dapat berupa memperkuat persatuan dan terus 
melakukan perluasan jaringan positif. Berikut tabel 6 klasifikasi modal sosial Tabel 6.

Klasifikasi Modal Sosial pada Petani Informan di Kelurahan Bintoro

\begin{tabular}{|l|l|l|}
\hline Variabel & Sub Variabel & \multicolumn{1}{|c|}{ Kesimpulan } \\
\hline Kepercayaan & $\begin{array}{l}\text { Manfaat } \\
\text { kepercayaan }\end{array}$ & $\begin{array}{l}\text { Manfaat dari adanya kepercayaan antar petani yaitu terjadi } \\
\text { kemudahan komunikasi, peminjaman alat, dan memperoleh } \\
\text { rezeki. }\end{array}$ \\
\cline { 2 - 3 } & $\begin{array}{l}\text { Perkembangan } \\
\text { kepercayaan }\end{array}$ & $\begin{array}{l}\text { Perkembangan kepercayaan yang berlangsung antar petani } \\
\text { yaitu sementara berkembang dengan sikap menjaga } \\
\text { kejujuran, sehingga banyak yang percaya antar petani } \\
\text { maupun masyarakat. }\end{array}$ \\
\hline Norma & $\begin{array}{l}\text { Perkembangan } \\
\text { norma }\end{array}$ & $\begin{array}{l}\text { Perkembangan norma di masyarakt petani masih terus } \\
\text { bertahan seperti saling menghormati dan menyayangi, } \\
\text { sehingga menciptakan kehidupan masyarakat yang rukun } \\
\text { dan damai tanpa ada suatu sanksi yang perlu diterapkan. }\end{array}$ \\
\hline Jarma & $\begin{array}{l}\text { Dampak norma di masyarakat petani yaitu akan } \\
\text { menciptakan masyarakat petani yang saling membantu dan } \\
\text { terjaganya kerukunan dengan contoh perolehan sumbangan } \\
\text { pada kegiatan pertanian jika mematuhi norma yang ada }\end{array}$ \\
\hline Jaringan & $\begin{array}{l}\text { Manfaat } \\
\text { jaringan }\end{array}$ & $\begin{array}{l}\text { Manfaat jaringan pada kegiatan pertanian yaitu membentuk } \\
\text { kemitraan, peningkatan penghasilan, bantuan modal, } \\
\text { jenambah ilmu, dan menjaga hubungan antar masyarakat } \\
\text { untuk saling menolong ketika terjadi musibah. }\end{array}$ \\
\hline & $\begin{array}{l}\text { Perkembangan jaringan yaitu sampai proses pembelajaran } \\
\text { ilmu baru yang berjalan cukup baik tanpa ada kendala, } \\
\text { meski masih terjadi kesalahpahaman dari kesalahan } \\
\text { pendengaran ataupun fitnah. Cara mengembangkan } \\
\text { jaringan melalui memperkuat persatuan dan akrab dengan } \\
\text { masyarakat. }\end{array}$ \\
\hline
\end{tabular}

\section{Kesimpulan}

Modal sosial memberikan nilai terhadap dukungan keberlanjutan pertanian di Kelurahan Bintoro. Bentuk konkrit dukungan modal sosial seperti terjalinnya hubungan harmonis di dalam kehidupan pertanian, tercipta rasa saling tolong menolong dan membantu sesama, berjalannya kegiatan pertanian, kemudahan di dalam memperoleh input atau fasilitas pertanian, dan beberapa bentuk lainnya. Berdasarkan kondisi tersebut meski terjadi alih fungsi lahan yang menjadi ancaman keberlanjutan pertanian, kegiatan pertanian masih terus dapat berjalan karena dasar kehidupan masyarakat petani yang masih kokoh di dalam mempertahankan keberlanjutan pertanian mereka.

\section{Saran}

1. Sebaiknya para petani membentuk ikatan hubungan yang lebih kuat antar sesama agar dapat mempertahankan lahan pertanian dari ancaman alih fungsi lahan

2. Memperluas jaringan dengan pihak lain,

3. Meningkatkan dan mempertahankan kepercayaan serta menjaga norma tetap berjalan dalam mengembangkan pertanian meski berada di tengah ancaman alih fungsi lahan.

\section{Ucapan Terimakasih}

Ucapan terimakasih saya ucapkan kepada Tuhan Yang Maha Esa dengan rahmatnya bisa menyelesaikan penelitian ini, ketua kelompok tani dan petani di kelurahan 
Bintoro sebagai informan untuk menggali informasi, dan pihak lain yang sudah mendukung untuk menyelesaikan penelitian ini.

\section{DAFTAR PUSTAKA}

Abdullah, S. 2013. Potensi dan Kekuatan Modal Sosial dalam Suatu Komunitas. Socius jurnal sosiologi. 12(1): 15-21.

Anggita, T. 2013. Dukungan Modal Sosial dalam Kolektivitas Usaha Tani Untuk mendukung Kinerja Produksi Pertanian Studi Kasus: Kabupaten Karawang dan Subang. Perencanaan Wilayah dan Kota, 24(3):203-226.

Berlian, M. 2014. Peran Penyuluh Pertanian Lapangan dan Partisipasi Petani dalam Program Feati serta Pengaruhnya terhadap Pendapatan Petani di Kecamatan Banyuasin Iii Kabupaten Banyuasin. Matematik, saint, dan Teknologi. 15(1): 22-32.

BPS Kabupaten Jember. 2018. Kecamatan Patrang dalam Angka 2017. Jember: Badan Pusat Statistik.

BPS Kabupaten Jember. 2019. Kecamatan Patrang dalam Angka 2018. Jember: Badan Pusat Statistik.

Daymon, C. dan I. Holloway. 2008. Metode-Metode Riset Kualitatif dalam Public Relations \& Marketing Communications. Yogyakarta: Bentang.

Fukuyama, F. 1999. Guncangan Besar Kodrat Manusia dan Tata Sosial Baru. Jakarta: PT. Gramedia Pustaka Utama.

Johnson, R. B. dan L. Christensen. 2017. Educational Research: Quantitative, Qualitative, and Mixed Approaches 6 Edition. Singapore: Sage Publications.
Miles, M. B., A. M. Huberman, and J. Saldana. 2014. A Qualitative Data Analysis A Methods Sourcebook. Los Angeles: Sage.

Raco, J. R. 2010. Metode Penelitian Kualitatif Jenis, Karakteristik, dan Keunggulannya. Jakarta: Grasindo.

Rahmadi, P.Z dan B. Santoso. 2016. Modal Sosial Petani Sawah Berlahan Sempit dalam Pemenuhan Nafkah Rumah Tangga. Analisa Sosiologi, 5(1):6273.

Sunarso. 2017. Strategi Pembangunan Pertanian yang Visioner dan Strategis. Sleman: Deepublish.

Suratiyah, K. 2015. Ilmu Usahatani. Jakarta: Penebar Swadaya. 